\title{
Peningkatan Kualitas Pembelajaran Kimia melalui Praktikum Titrasi di SMA Negeri 5 Balikpapan
}

\author{
Ashadi Sasongko', Sri Sulastri², Adrian Gunawan ${ }^{3}$, Moch Purwanto ${ }^{4}$ \\ ${ }^{1,3,4}$ Institut Teknologi Kalimantan, Balikpapan, Kalimantan Timur \\ ${ }^{2}$ SMA Negeri 5 Balikpapan, Kalimantan Timur \\ email : ashadisasongko@ lecturer.itk.ac.id ${ }^{1}$, dewisulastri4@gmail.com², a.gunawan@lecturer.itk.ac.id ${ }^{3}$, \\ m.purwanto@lecturer.itk.ac.id ${ }^{4}$
}

\begin{abstract}
The availability of chemistry laboratories in high schools is needed to improve the quality of learning through experimental methods. The adequacy of the number of teachers and laboratory assistants also greatly influenced the smooth implementation of the experiment. SMA Negeri 5 Balikpapan is one of the well-known high schools that has adequate chemical tools and materials, but has experienced a vacuum in experimental activities. The team of lecturers and students of the Chemical Engineering Study Program in the Kalimantan Institute of Technology (ITK) identified to find out the tools and materials that could be used. The identification results show that the tools and materials available are adequate for a variety of chemistry experiment materials, including acid-base titration, which are difficult material in chemistry. Guidance of experiment was prepared to be a reference for students. Pre-test and post-test are used to determine the impact of the implementation of the titration. Titration experiment shows a significant impact in optimizing the use of chemical laboratories and increasing students' understanding of acid-base titration.
\end{abstract}

Keywords: experiment, titration, high school chemistry.

\begin{abstract}
Abstrak
Ketersediaan laboratorium kimia di SMA sangat diperlukan untuk meningkatkan kualitas pembelajaran melalui metode praktikum. Kecukupan jumlah guru dan laboran juga sangat mempengaruhi kelancaran pelaksanaan praktikum. SMA Negeri 5 Balikpapan merupakan salah satu SMA ternama yang memiliki alat dan bahan praktikum kimia cukup memadai, namun sempat mengalami kekosongan kegiatan praktikum. Tim dosen dan mahasiswa Prodi Teknik Kimia Institut Teknologi Kalimantan (ITK) melakukan identifikasi untuk mengetahui alat dan bahan yang dapat digunakan. Hasil identifikasi menunjukkan bahwa alat dan bahan yang ada memadai untuk berbagai materi praktikum kimia, termasuk praktikum titrasi asam basa, yang termasuk materi sulit dalam ilmu kimia. Modul praktikum disiapkan untuk menjadi acuan bagi siswa. Pre-test dan post-test digunakan untuk mengetahui dampak pelaksanaan praktikum titrasi. Praktikum titrasi menunjukkan dampak yang signifikan dalam mengoptimalkan pemanfaatan laboratorium kimia dan meningkatkan pemahaman siswa terhadap titrasi asam basa.
\end{abstract}

Kata Kunci: praktikum, titrasi, kimia SMA.

Artikel diterima : 11 Februari 2020 $\quad$ revisi : 8 Juni $2020 \quad$ setujui : 27 Juli 2020 


\section{Pendahuluan}

Proses belajar-mengajar pada dasarnya merupakan proses interaksi antara siswa, pengajar, dan lingkungannya, sehingga menghasilkan perubahan perilaku menuju yang lebih baik. Perubahan yang dimaksud mencakup perubahan pengetahuan (kognitif), ketrampilan (psikomotorik), dan perubahan sikap (afektif). Interaksi dalam proses belajar-mengajar dipengaruhi oleh faktor internal dari individu yang terlibat, dan faktor eksternal yang berasal dari lingkungan. Akan tetapi secara sederhana, proses belajar-mengajar dapat didefinisikan sebagai proses yang mencakup serangkaian kegiatan pengajar dan siswa atas dasar hubungan timbal balik yang berlangsung dalam situasi yang kondusif untuk mencapai tujuan yang ditetapkan (Utomo, 2011).

Pembelajaran sains tidak hanya bertujuan untuk menghafal rumus, memahami pengetahuan, sikap dan ketrampilan, namun juga untuk memberikan kesempatan agar siswa dapat terlibat dan belajar dengan cara menggunakan alur berpikir ilmiah. Pembelajaran kimia, sebagai salah satu sains, dikembangkan berdasarkan pada metode induktif (melalui percobaan/ praktikum) ataupun berdasarkan metode deduktif (pengajaran teori/konsep), sehingga siswa diharapkan terlatih untuk berpikir secara ilmiah. Ada tiga tahapan penting yang harus dilakukan oleh pengajar dalam pembelajaran kimia, yaitu perencanaan, pelaksanaan, dan evaluasi.

Ilmu kimia memiliki karakter yang unik, sehingga dalam mempelajarinya diperlukan metode tertentu tanpa meninggalkan karakteristik ilmu kimia sebagai prosedur dan proses. Beberapa karakter ilmu kimia antara lain: a) kimia lebih bersifat abstrak, b) kimia berkaitan dengan kehidupan sehari- hari, c) bahan pelajaran kimia dimulai dari yang dasar menuju yang sukar, dan d) pelajaran kimia tidak hanya menyelesaikan soal-soal.
Metode pembelajaran kimia untuk hal yang bersifat abstrak tersebut adalah dengan cara berimajinasi atau menciptakan ilustrasi yang memperjelas imajinasi. Ilustrasi dapat membantu siswa mengingat materi yang dibahas dalam ilmu kimia seperti atom, molekul, ikatan dan lain-lain. Bahan kimia yang ada di dunia ini kebanyakan terdiri dari senyawa yang kompleks dan sulit dipelajari. Oleh karena itu, pembelajaran kimia dimulai dari zat-zat yang sederhana. Dengan kata lain, pembelajaran kimia akan menjadi lebih mudah jika disampaikan secara sistematis mulai dari konsep yang mudah menuju yang lebih sulit.

Ilmu kimia mempelajari teori, hukum-hukum alam, fakta, deskripsi dan istilah-istilah kimia. Semua pengetahuan tersebut bermanfaat untuk memecahkan soal. Persoalannya, ilmu kimia bukan hanya penyelesaian soal saja. Sebelum siswa mampu mengerjakan soal, siswa harus memahami konsep kimia yang telah diajarkan sehingga dapat menerapkan konsep tersebut dalam mengerjakan soal. Pengajar di sekolah maupun dosen di kampus dituntut menciptakan suasana belajar yang melibatkan siswa / mahasiswa secara aktif.

Dengan memodifikasi pembelajaran melalui pendekatan yang berpusat pada siswa, maka tujuan pembelajaran kimia di sekolah dapat dinyatakan sebagai berikut: a) menyiapkan dasar-dasar pengetahuan sebagai bekal aplikasi di masa depan, b) menanamkan kepada siswa bahwa kimia merupakan bagian dari kehidupan sehari-hari, dan c) menjalankan kurikulum yang dapat diterapkan oleh semua tipe guru.

Agar dapat memanfaatkan ilmu kimia yang dimiliki, siswa perlu belajar berpikir kimia. Hal ini menuntut metode pembelajaran kimia di Indonesia perlu diubah agar dapat membekali siswa dengan keterampilan berpikir, dari mempelajari kimia menjadi berpikir melalui kimia, dan di level selanjutnya menjadi berpikir kimia. 
Dengan demikian, tujuan pokok pembelajaran kimia adalah agar siswa mempunyai kemampuan berfikir dan bertindak berdasarkan pengetahuan kimia yang dimiliki, atau lebih dikenal dengan istilah keterampilan generik kimia (Utomo, 2011).

Variasi metode pembelajaran dapat memperbaiki motivasi siswa dalam belajar. Metode yang interaktif perlu direncanakan dan diterapkan oleh guru dalam proses pembelajaran. Praktikum merupakan metode yang sangat sesuai untuk mengajarkan konsep-konsep sains yang bersifat abstrak, namun dikembangkan berdasarkan fakta ilmiah yang terjadi (Bahriah dan Abadi, 2016) (Lestari, 2012).

Praktikum yang diterapkan sebagai metode dalam pembelajaran kimia sangat sesuai dengan tujuan pendidikan yang mencakup tiga aspek, mengembangkan pengetahuan, menanamkan sikap ilmiah, dan melatih keterampilan. Dengan adanya praktikum seorang siswa akan terlatih menggunakan alat-alat di laboratorium kimia dengan baik, mengenal bahan-bahan kimia, dan pemahamannya tentang konsepkonsep kimia akan lebih mendalam. Hal ini sesuai dengan yang pendapat dikemukakan Edgar Dale bahwa informasi yang diterima oleh siswa $75 \%$ diperoleh melalui indera penglihatan. Artinya melalui praktikum, siswa dapat melihat dan mengamati fenomena kimia secara lebih jelas (bukan hanya berimajinasi), sehingga informasi yang didapatkan akan lebih banyak dibandingkan dengan sekedar mendengar. Pembelajaran yang disertai dengan pengamatan, selain dapat menarik perhatian siswa juga dapat meningkatkan pemahaman karena sesuatu yang dilihat akan melekat lebih lama dalam pikiran. Praktikum dapat pula meningkatkan minat dan motivasi belajar siswa, memperjelas pemahaman, dan memberikan pengalaman yang lebih komprehensif (Utomo, 2011).

Praktikum merupakan salah satu bentuk dari keterampilan proses yang dapat diupayakan dengan ketersediaan fasilitas laboratorium. Praktikum di laboratorium mempunyai manfaat ganda, yaitu membe- rikan pengalaman kerja kimia secara nyata, dan mendorong siswa agar berlatih berpikir dengan cara kritis dan ilmiah. Secara rinci tujuan kegiatan praktikum di laboratorium antara lain (Utomo, 2011): 1.Merencanakan dan melaksanakan kerja di laboratorium dengan menggunakan fasilitas secara efektif; 2.Mengembangkan keterampilan pengamatan, instrumentasi, dan preparasi; 3.Memperoleh pengetahuan kimia; 4.Mendorong pikiran untuk menginterpretasikan eksperimen; 5.Mengenal ketelitian dan keterbatasan kerja laboratorium; 6.Merekam secara cermat dan mengomunikasikan hasil secara jelas; dan 7.Mengembangkan tanggung jawab perorangan dan reliabilitas dalam pelaksanaan eksperimen.

Menurut Bahriah dan Abadi (2016) praktikum merupakan metode pembelajaran yang sangat efektif untuk memahami konsep-konsep ilmu kimia. Pembelajaran ilmu kimia yang merupakan bagian dari sains, tidak cukup hanya dengan mengajarkan konsep, namun perlu juga menekankan proses menuju konsep tersebut yang dapat terbentuk melalui proses ilmiah dalam kegiatan praktikum.

Metode pembelajaran melalui praktikum berpusat kepada siswa (student centered learning). Siswa memiliki peran yang sangat dominan dalam kegiatan praktikum, karena guru hanya berperan sebagai fasilitator. Siswa dituntut berlatih untuk memecahkan permasalahan secara mandiri. Hal tersebut tidak bisa dicapai jika proses pembelajaran hanya dilakukan dengan metode ceramah, di mana siswa pada kondisi tertentu akan mengalami kejenuhan (Bahriah dan Abadi, 2016) (Hidayati, 2012).

Ilmu kimia berkembang melalui pendekatan eksperimen, sehingga, ketersediaan laboratorium di sekolah sangat dibutuhkan untuk mendukung proses pembelajaran dan dapat membentuk karakter ilmiah siswa (Emda, 2014). Laboratorium diharapkan menjadi sarana untuk mendalami materi melalui praktikum. Namun tantangan dan hambatan dalam proses pembelajaran melalui praktikum 
cukup banyak, khususnya di berbagai sekolah, termasuk di SMA Negeri 5 Balikpapan. SMAN 5 Balikpapan merupakan sekolah yang cukup dikenal, dengan jumlah siswa jurusan IPA yang cukup banyak.

Jumlah guru kimia dan laboran yang tidak ideal menyebabkan terhambatnya pelaksanaan praktikum kimia di sekolah. Laboratorium kimia SMA Negeri 5 Balikpapan memiliki fasilitas alat dan koleksi bahan kimia yang cukup banyak. Peran laboratorium perlu dioptimalkan untuk mendukung proses pembelajaran kimia. Materi titrasi asam basa menjadi prioritas untuk dapat dilaksanakan praktikumnya.

Titrasi asam basa adalah salah satu topik penting dalam kimia SMA. Berdasarkan penelitian Amzar dkk. (2018) terungkap bahwa sebagian besar guru mengabaikan topik ini, karena guru kesulitan mencari metode terbaik untuk mengajarkan topik secara efektif dan efisien. Praktikum titrasi asam basa dapat meningkatkan kemampuan berpikir siswa tentang cara mengomunikasikan data titrasi asam basa. Penelitian Widarti dkk (2017) terhadap 66 siswa menunjukkan bahwa hanya $51,6 \%$ siswa yang memahami konsep titrasi dengan baik; 13,3\% siswa tidak memahami konsep tersebut, dan $35,1 \%$ siswa memiliki kesalahpahaman.

Pendampingan praktikum di SMA Negeri 5 Balikpapan dirasa dapat memberikan dampak signifikan pada sekolah favorit di Kalimantan Timur ini, yang telah dilengkapi dengan berbagai fasilitas laboratorium, termasuk laboratorium kimia. Stimulasi tim dosen pengabdi dari Institut Teknologi Kalimantan (ITK) dinilai perlu, mengingat keterbatasan kuantitas SDM guru maupun laboran yang ada.

\section{Pelaksanaan dan Metode}

Pelaksanaan kegiatan ini terbagi dalam 5 (lima) tahap sebagai berikut: 1.Inventarisasi Alat dan Bahan; 2.Perancangan Topik Praktikum Titrasi Asam
Basa; 3.Koordinasi dengan Guru Pengajar; 4.Pembekalan Asisten Praktikum; 5.Pelaksanaan \& Evaluasi Praktikum

\section{Inventarisasi Alat dan Bahan Kimia}

Tahap ini meliputi identifikasi, pencatatan, penggolongan dan penataan ulang bahan-bahan kimia berdasarkan wujud dan sifatnya. Hal ini akan memudahkan pencarian bahan yg dibutuhkan, termasuk untuk praktikum titrasi. Kegiatan ini dibantu oleh para alumni SMAN 5 Balikpapan yang kuliah di Prodi Teknik Kimia ITK.

\section{Perancangan Topik Praktikum Titrasi Asam Basa}

Kegiatan ini membutuhkan penyesuaian dari 2 aspek, ketersediaan bahan dan kurikulum yang berlaku. Pada tahap ini, modul praktikum dan soal pre-test/post-test juga disiapkan. Berikut ini (Gambar 1 dan 2) adalah gambaran ringkas soal pre-test / post-test dan panduan praktikum.

\section{Soal Tes}

1) Berapa $\mathrm{mL} \mathrm{NaOH} 0,1 \mathrm{M}$ yang dibutuhkan untuk menyiapkan larutan $\mathrm{NaOH}$ sebanyak 2 milimol ?

2) Berapa volume $\mathrm{NaOH} \mathrm{0,2} \mathrm{M}$ yang dibutuhkan untuk menetralkan $\mathrm{HCl} 0,1$ M sebanyak $10 \mathrm{~mL}$ ?

3) Molaritas dapat dikonversi ke dalam satuan \% massa/volume. Maka $\mathrm{NaOH}$ $1 \mathrm{M}$ setara dengan ... \% massa/volume.

4) Apa fungsi titrasi ?

Gambar 1. Soal pre-test / post test 


\section{Penentuan Kadar Asam Asetat dalam Cuka Dapur}

1. Pipet $10 \mathrm{~mL}$ sampel cuka ke dalam erlenmeyer dan tambahkan 3 tetes indikator phenolphtalein (PP). Tambahkan akuades jika perlu (penambahan ini tidak mempengaruhi jumlah mol asam asetat di dalam erlenmeyer)

2. Jika perlu, letakkan kertas putih di bawah erlenmeyer untuk memperjelas pengamatan perubahan warna pada waktu titrasi.

3. Baca skala awal pada buret yang telah diisi $\mathrm{NaOH}$. Larutan cuka dititrasi dengan $\mathrm{NaOH} 0,2 \mathrm{M}$ sampai berubah warna menjadi merah muda. Catat volume $\mathrm{NaOH}$ yang terpakai.

Skala awal

Skala akhir

Volume terpakai :

$\mathrm{Mol} \mathrm{NaOH}$ terpakai :

4. Titik akhir titrasi terjadi saat terbentuk warna pink. Jumlah mol asam sama dengan mol basa Reaksi :

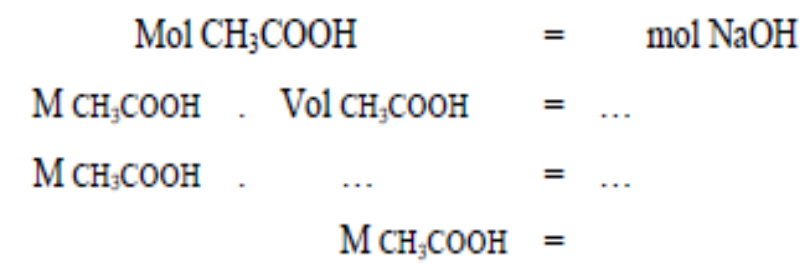

5. Nyatakan konsentrasi $\mathrm{CH}_{3} \mathrm{COOH}$ dalam $\%$ massa / volume (gram $/ 100 \mathrm{~mL}$ )!

Petunjuk : Molaritas menunjukkan jumlah mol dalam 1 Liter.

$$
1 \mathrm{M}=1 \mathrm{~mol} / 1 \mathrm{~L} ; \text { atau } 1 \mathrm{M}=100 \mathrm{milimol} / 100 \text { miliLiter }
$$

\section{Gambar 2. Prosedur Praktikum}

\section{Koordinasi dengan Guru Pengajar}

Koordinasi dilakukan dengan guru pengajar untuk menjadwalkan kelas dan waktu yang sesuai. Sasaran kegiatan praktikum ini adalah siswa kelas XI, yang telah mendapatkan materi teori tentang asam-basa.

\section{Pembekalan Asisten Praktikum}

Pembekalan dilakukan oleh tim dosen Teknik Kimia ITK terhadap asisten yang merupakan para alumni SMAN 5 Balikpapan yang kuliah di Prodi Teknik Kimia ITK. Sebagian besar dari asisten juga berpengalaman menjadi asisten praktikum kimia dasar di kampus ITK.

\section{Pelaksanaan \& Evaluasi Praktikum}

Praktikum dilaksanakan di bawah arahan tim dosen ITK dan guru SMAN 5. Teknis pelaksanaan di lapangan dikoordinasikan oleh asisten praktikum, didukung oleh 1 (satu) orang laboran SMAN 5 Balikpapan yang baru direkrut oleh pihak sekolah. 


\section{Hasil dan Pembahasan}

Beberapa strategi dilakukan dalam rangka optimalisasi peran Laboratorium Kimia SMA Negeri 5 Balikpapan untuk meningkatkan kualitas pembelajaran. Hal ini juga didukung oleh kemauan kuat dari pihak sekolah untuk mengaktifkan kembali kegiatan praktikum.

Inventarisasi alat dan bahan kimia (Gambar 3 dan 4) berhasil memetakan persediaan kebutuhan untuk materi-materi praktikum, termasuk untuk materi titrasi asam basa.

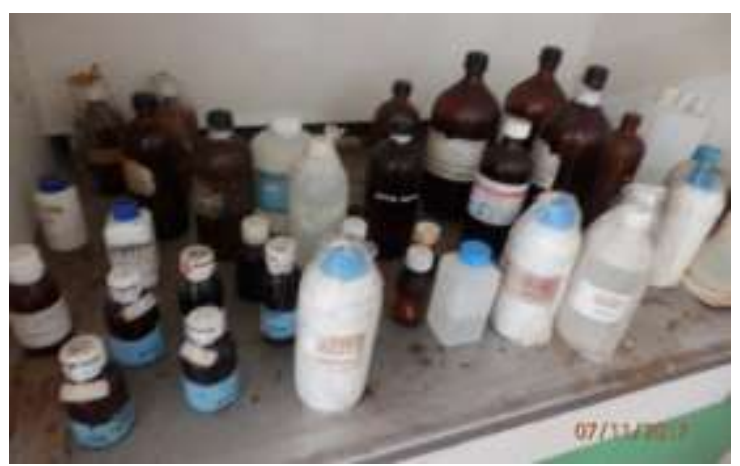

Gambar 3. Bahan-bahan cair

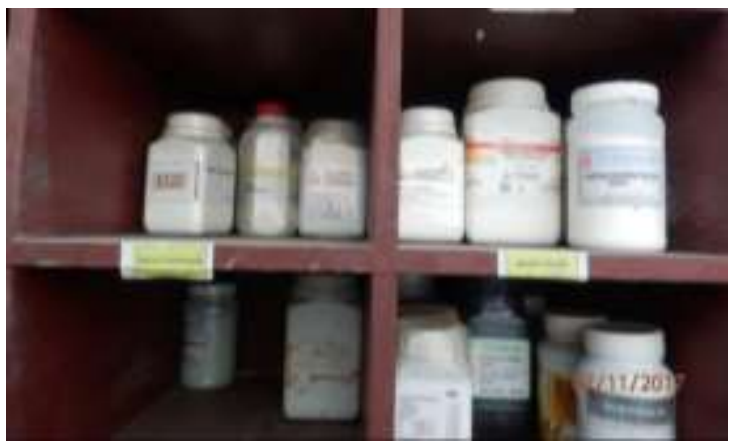

Gambar 4. Bahan-bahan padat

Praktikum dilaksanakan secara berkelompok, di mana setiap kelompok terdiri atas maksimal 5 orang yang didampingi oleh 1 orang asisten, mengadopsi model praktikum yang dilaksanakan di ITK. Sistem kelompok kecil ini tergolong ideal karena memungkinkan semua siswa anggota kelompok dapat terlibat aktif dalam praktikum (Gambar 5 s.d. 10).

Sebelum praktikum dilaksanakan, siswa diberikan soal pre-test dan penjelasan teknis praktikum. Pre-test bertujuan mengukur sejauh mana pemahaman siswa terhadap materi yang telah disampaikan di kelas oleh guru. Penjelasan teknis praktikum bertujuan untuk memberikan gambaran umum tentang apa yang akan dikerjakan selama praktikum.

Pihak sekolah memberikan dukungan agar praktikum dapat dilaksanakan untuk seluruh kelas XI IPA yang berjumlah 6 kelas. Gambar 3 dan 4 menunjukkan pelaksanaan kegiatan praktikum titrasi asam basa di Laboratorium Kimia SMAN 5 Balikpapan.

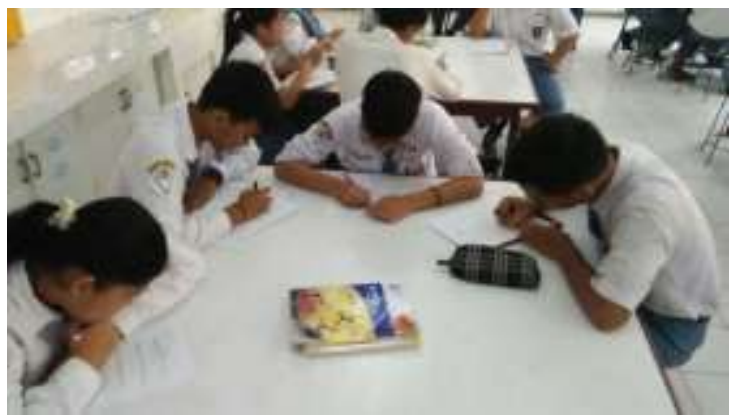

Gambar 5. Suasana pre-test

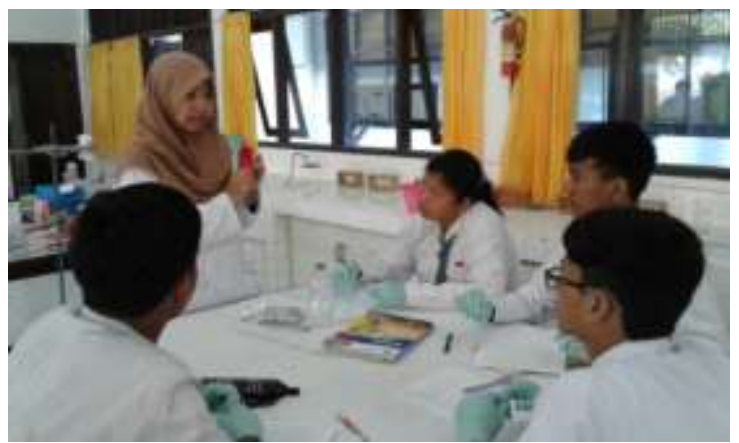

Gambar 6. Penjelasan penggunaan alat

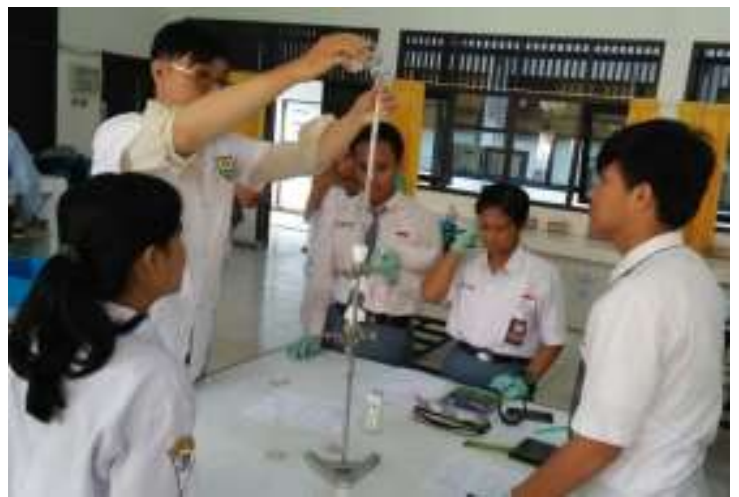

Gambar 7. Persiapan praktikum 


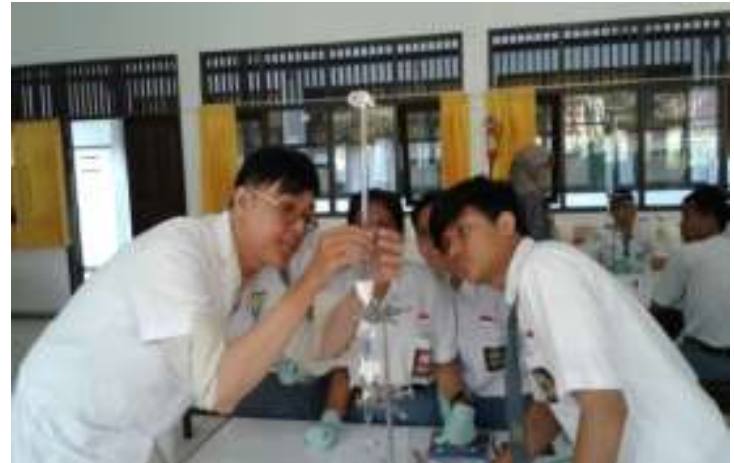

Gambar 8. Pembacaan skala buret

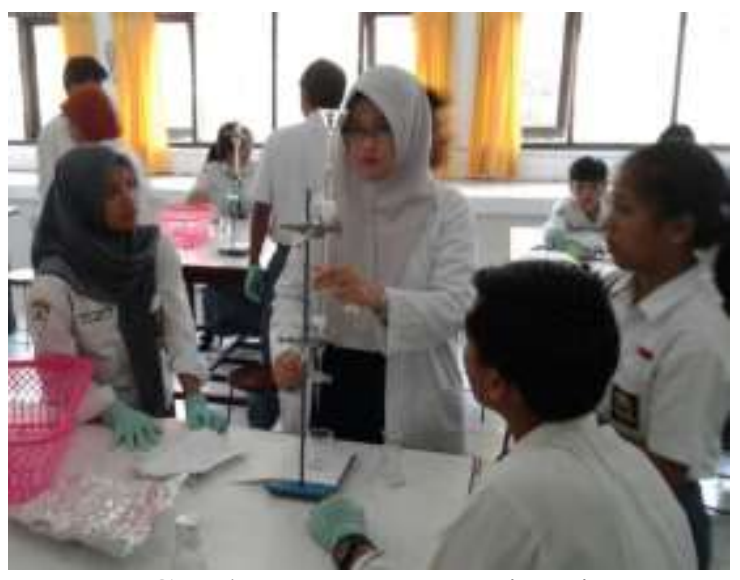

Gambar 9. Peragaan titrasi

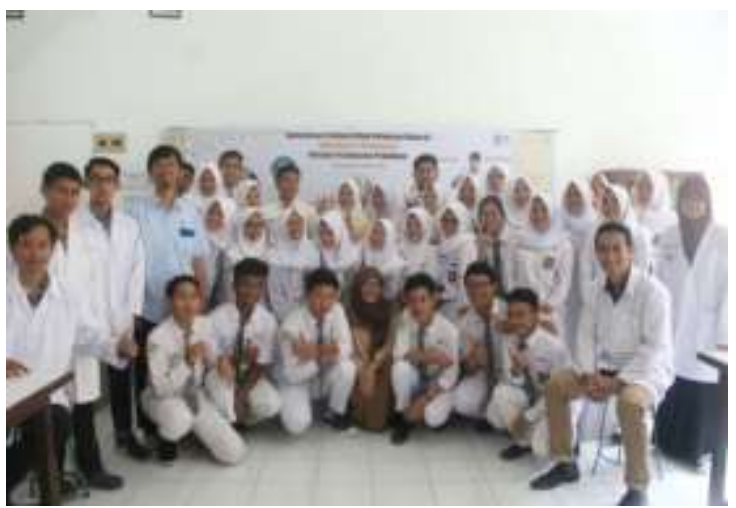

Gambar 10. Tim dosen, asisten, dan siswa

Proses pembelajaran melalui metode praktikum berpengaruh positif terhadap pemahaman siswa. Berdasarkan hasil posttest yang dilakukan setelah menggunakan pembelajaran praktikum, terlihat bahwa terjadi peningkatan hasil belajar yang signifikan.

Metode praktikum mencakup unsur percobaan yang dapat melatih siswa untuk dapat menemukan hasil yang nyata dan dapat mengaitkan hasil dengan teori yang mereka pelajari, sehingga siswa dapat menggunakan pikirannya untuk menyimpulkan hasil yang didapat. Kemudian unsur diskusi untuk memantapkan hasil yang telah dirumuskan. Selanjutnya siswa untuk melaporkan hasil praktikum agar pembelajaran yang sudah dilaksanakan dapat ditulis secara sistematis meskipun relatif ringkas.

Dalam praktikum ini, siswa mendalami konsep titrasi. Pada umumnya, siswa telah memahami fungsi titrasi, khususnya titrasi asam basa. Sebanyak $70 \%$ siswa telah mengetahui secara umum fungsi titrasi dalam menentukan konsentrasi larutan yang belum diketahui. Dengan adanya praktikum ini, semakin banyak siswa yang memahami fungsi titrasi. Sebagian besar siswa juga mampu menuliskan reaksi asam basa yang terjadi pada praktikum titrasi.

Di antara siswa juga ada yang belum mampu menghitung konsentrasi larutan menggunakan persamaan titrasi. Ada juga siswa yang mengira bahwa persamaan titrasi sama dengan persamaan pengenceran. Pengenceran hanya melibatkan satu senyawa dengan pelarutnya yang tidak mengakibatkan reaksi. Sedangkan pada titrasi asam basa terdapat 2 (dua) reaktan yang saling bereaksi.

Tabel 1 menunjukkan adanya peningkatan persentase siswa yang mampu menghitung konsentrasi larutan dengan metode titrasi, dari $60 \%$ menjadi $80 \%$. Sebelum praktikum, persentase siswa yang sudah mampu menghitung konsentrasi larutan dengan metode titrasi tergolong tinggi karena pada umumnya siswa banyak mendapat latihan soal terkait perhitungan tersebut.

Konversi satuan konsentrasi larutan masih dirasa sulit oleh para siswa, terbukti dengan persentase mahasiswa yang mampu mengkonversi satuan konsentrasi larutan hasil titrasi hanya mencapai $10 \%$. Dengan pelaksanaan praktikum titrasi, persentase siswa yang mampu mengkonversi satuan konsetrasi larutan mengalami peningkatan yang sangat signifikan hingga menyentuh angka $70 \%$. Kemampuan mengkonversi satuan konsentrasi merupakan hal yang 
sangat penting karena berkaitan langsung dengan kehidupan sehari-hari. Misalnya cuka yang ada di pasaran memiliki konsentrasi $\mathrm{X} \%$, maka siswa sewajarnya mampu menyatakan konsentrasi tersebut dalam satuan lain, misalnya molar.

Secara umum, kegiatan praktikum titrasi untuk siswa kelas XI SMA Negeri 5 Balikpapan telah memberikan stimulan untuk meningkatkan kualitas dan capaian pembelajaran kimia. Nilai rata-rata siswa yang hanya 46.88 saat pre-test meningkat menjadi 73.75 pada saat post-test. Rentang nilai yang dicapai oleh siswa juga meningkat, dari 25 - 55 menjadi 60 - 80.

Tabel 1. Analisis hasil kegiatan praktikum

\begin{tabular}{lcc}
\hline & Pre-test & Post-test \\
\hline Skor rata-rata & 46.88 & 73.75 \\
\hline Rentang skor & $25-55$ & $60-80$ \\
\hline $\begin{array}{l}\text { Siswa yang paham } \\
\text { tentang fungsi titrasi }\end{array}$ & $70 \%$ & $80 \%$ \\
\hline $\begin{array}{l}\text { Siswa yang mampu } \\
\text { menghitung }\end{array}$ & $60 \%$ & $80 \%$ \\
$\begin{array}{l}\text { konsentrasi dengan } \\
\text { persamaan titrasi }\end{array}$ & & \\
\hline $\begin{array}{l}\text { Siswa yang mampu } \\
\text { mengkonversi satuan } \\
\text { konsentrasi larutan } \\
\text { hasil titrasi }\end{array}$ & $10 \%$ & $70 \%$ \\
\hline
\end{tabular}

Dengan adanya kegiatan pengabdian kepada masyarakat dalam bentuk pendampingan praktikum ini, sekolah semakin giat untuk memberdayakan potensi laboratorium, guna meningkatkan kualitas pembelajaran.

Berikut rangkuman beberapa alasan pentingnya kegiatan praktikum sains, terutama kimia: 1.Praktikum meningkatkan motivasi belajar sains. Melalui praktikum di laboratorium, siswa mendapat kesempatan untuk memenuhi dorongan rasa ingin tahu dan ingin bisa. Prinsip ini akan menunjang kegiatan praktikum di mana siswa menemukan pengetahuan melalui eksplorasinya terhadap alam; 2.Praktikum dapat mengembangkan keterampilan dasar bereksperimen. Kegiatan praktikum melatih siswa untuk mengembangkan kemampuan bereksperimen dengan melatih kemampuan observasi dengan cermat, mengukur secara akurat dan aman, merancang, mengerjakan dan menginterpretasikan hasil yang diperoleh; 3.Praktikum menjadi wahana belajar melalui pendekatan ilmiah; 4.Praktikum dapat menunjang pemahaman siswa terhadap materi pelajaran.

Pengalaman belajar yang diperoleh siswa melalui proses aksi perbuatan atau mengalami sendiri apa yang dipelajari, adalah suatu pengalaman langsung. Semakin konkrit siswa mempelajari bahan pelajaran maka semakin banyak pengalaman ilmiah yang diperoleh.

Selain rangkuman tersebut, tim juga membuat rekomendasi berikut : 1 .Semua topik dalam kimia yang berorientasi praktis sedapat mungkin dilaksanakan praktikumnya di laboratorium, menggunakan semua peralatan dan bahan kimia yang diperlukan. Dengan menggunakan bahan kimia/ reagen, para siswa akan memperoleh keterampilan yang terlibat dalam menangani zat berbahaya; 2.Semua laboratorium kimia di sekolah harus dilengkapi dengan peralatan yang memadai dan alat bantu pengajaran lainnya seperti model molekul alat lain yang diperlukan. Penyediaan bahan/peralatan ini akan membantu guru dan siswa dalam proses belajar mengajar; 3.Para guru kimia harus didorong untuk menghadiri konferensi, seminar dan lokakarya. Ini akan membantu para guru mempelajari hal-hal baru, metode, dan memperoleh keterampilan baru dalam mengajar konsep kimia yang sulit; 4.Para guru kimia harus dimotivasi melalui insentif/tunjangan khusus sesuai regulasi yang berlaku; 5.Ada penjadwalan khusus untuk praktikum dalam mata pelajaran kimia; 6.Para guru dan siswa mereka harus menggunakan buku teks kimia yang direkomendasikan oleh pemerintah; 7.Harus ada peningkatan anggaran untuk membiayai operasional dan pembelian alat / bahan kimia laboratorium.

\section{Simpulan}

\section{Penutup}

Kegiatan pengabdian kepada masyarakat dengan tema besar "Optimalisasi 
Edukasi Mata Pelajaran Kimia Di SMA Negeri 5 Balikpapan Melalui Pendekatan Praktikum" telah mengoptimalkan fungsi laboratorium dan meningkatkan pemahaman siswa melalui praktikum, khususnya topik titrasi asam basa.

\section{Saran}

Kegiatan pendampingan seperti ini perlu dijaga keberlanjutannya, dengan memberdayakan alumni sekolah yang sedang kuliah, sebagai asisten praktikum di berbagai sekolah di Balikpapan dan daerah lain di Kalimantan Timur. Hal ini juga mendukung pelaksanaan standar nasional pendidikan tinggi (SN Dikti) terbaru yang mewajibkan mahasiswa memiliki kegiatan pengabdian kepada masyarakat sebagai salah satu syarat kelulusan.

\section{Ucapan Terima Kasih}

Terima kasih kepada Lembaga Penelitian dan Pengabdian Masyarakat Institut Teknologi Kalimantan (LPPM ITK) yang telah mendukung pelaksanaan program ini, dan SMA Negeri 5 Balikpapan sebagai mitra.

\section{Daftar Pustaka}

Amzar, M., Hendayana, S., Wahyu, W., Supriatna, A., Lestiyani, S., Collaborative Lesson Design of Acid-Base Titration Curve in Indonesia Senior High School, International Conference on Mathematics and Science Education of Universitas Pendidikan Indonesia Vol. 3, 2018

Bahriah, E. S., Abadi, S. M., Motivasi Belajar Siswa Pada Materi Ikatan Kimia Melalui Metode Praktikum, EduChemia, Vol.1, No.1, 2016

Emda, A., Laboratorium sebagai Sarana Pembelajaran Kimia dalam Meningkatkan Pengetahuan dan Ketrampilan Kerja Ilmiah Lantanida Journal, Vol. 2 No. 2, 2014

Hidayati, N., Penerapan Metode Praktikum Dalam Pembelajaran Kimia Untuk
Meningkatkan Keterampilan Berfikir Tingkat Tinggi Siswa Pada Materi Pokok Kesetimbangan Kimia Kelas XI SMK Diponegoro Banyuputih Batang, Fakultas Tarbiyah Institut Agama Islam Negeri Walisongo, Semarang, 2012

Lestari, W., Susilowati, E., Mahardiani, L., Nugroho, A., Pembelajaran Kimia Melalui Pendekatan Contextual Teaching And Learning (CTL) dengan Metode Praktikum yang Dilengkapi dengan Lembar Kerja Siswa (LKS) dan Diagram Vee Ditinjau dari Sikap Ilmiah Siswa pada Materi Pokok Perubahan Materi Kelas VII Semester Genap Di MTSN 1 Surakarta Tahun Ajaran 2011/2012, Jurnal Pendidikan Kimia (JPK), Vol. 1 No. 1, 2012

Utomo, M.P., Makalah Pengabdian Pada Masyarakat Adaptasi Pelaksanaan Praktikum Kimia Negara OECD, 4 Juni 2011, FMIPA UNY

Widarti, H. R., Permanasari, A., Mulyani, S., Students' Misconceptions on Titration, IOP Conf. Series: Journal of Physics: Conf. Series 812 (2017) 012016 